\title{
Rutile U-Pb dating in diamond exploration - application to detrital heavy mineral provenance studies and kimberlite age dating
}

\author{
Wayne R. Taylor ${ }^{1,2,3}$ \\ ${ }^{1}$ Elkedra Diamonds NL, Subiaco, WA 6008 (wayne.taylor@elkedra.com.au) \\ ${ }^{2}$ RSES, Australian National University, Canberra, ACT 0200, Australia \\ ${ }^{3}$ present address: Uramet Minerals Ltd, PO Box 8280, Subiaco East, WA 6008, Australia
}

Rutile is a common detrital mineral in heavy mineral concentrates obtained from stream sediment surveys in diamond exploration programs. Niobian rutile is also an accessory mineral found in some kimberlites. Rutile can be rapidly and accurately dated (U-Pb system) by UV-laser-ablation (LA) ICPMS methods.

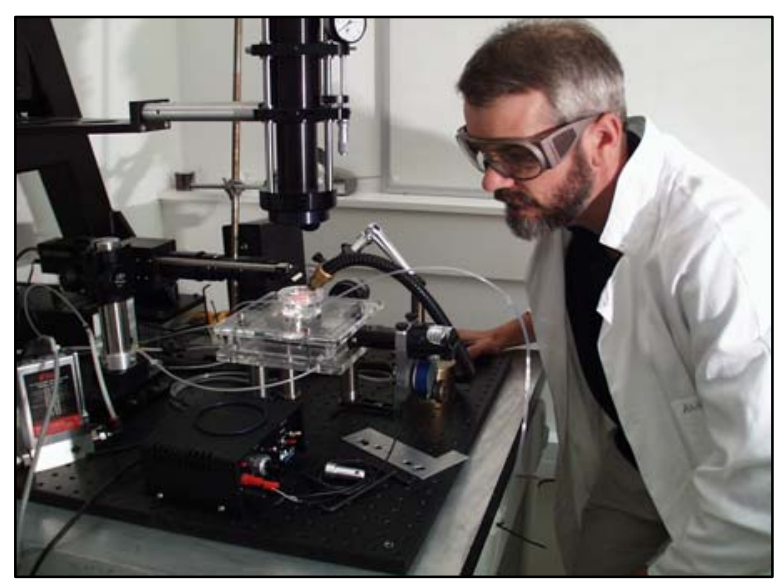

Fig.1 ArF UV (193 nm) excimer laser system coupled to an Agilent 7500 s quadrupole ICPMS at RSES, ANU, Canberra. The figure shows the He atmosphere ablation cell with stratified Ar flow. The post-ablation gas is transported to the plasma torch via a signal smoothing manifold. The laser is run at 5 pulses/second and $100 \mathrm{~mJ}$. Typical spot size for rutile dating is 100 microns.

Rutile is in many ways ideal for LA-ICPMS dating in that unlike zircon, it typically has low levels of common $\mathrm{Pb}$ and its lower reset temperature of about $600{ }^{\circ} \mathrm{C}$ means that inherited cores are not common. A standard rutile, previously dated by SHRIMP, was analysed twice for each batch of eight rutile grains.

\section{Why LA-ICPMS?}

- Fast and cost effective - over 100 grains can be analysed in one 8 hour session

- Dates are generally accurate to a few Ma - not as precise as the SHRIMP but perfectly adequate for dating and provenance studies

\section{New Applications}

- Dating kimberlite pipes using kimberlitic Nb-Crrutile

- Provenance studies using detrital rutile from heavy mineral concentrates in stream catchments containing indicators and/or diamonds

- Targeting Nb-rutile and Nb-ilmenorutile as alkaline rock indicator minerals from which an age can also be obtained

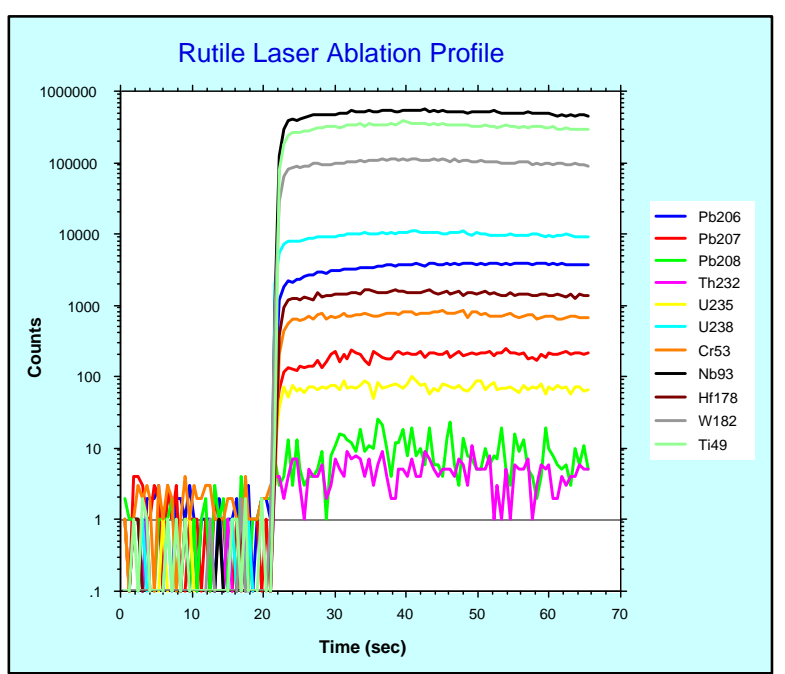

Fig. 2 Typical LA-ICPMS trace element isotope profiles for a detrital niobian rutile grain from the Georgina Basin. As well as $\mathrm{Pb}$ and $\mathrm{U}$ isotopes other trace elements such as $\mathrm{Nb}, \mathrm{Cr}, \mathrm{W}$ can be routinely analysed for grain characterization. Note the low common lead $\mathrm{Pb}^{208}$ abundance (bright green). The U$\mathrm{Pb}$ date of this grain is $350 \pm 6 \mathrm{Ma}$.

Application to kimberlite age dating using $\mathrm{Cr}-\mathrm{Nb}$ rutile from a kimberlite heavy mineral concentrate.

In the North Kimberley kimberlite province of northwestern Australia $\mathrm{Cr} \pm$ Nb-rutile grains are present in the heavy mineral concentrates of a number of kimberlite pipes. It has been assumed that all pipes of this province are of Neoproterozoic age, approx. 800Ma old, although a number of pipes have not been previously dated. 
In the present study the following ages have been obtained:

$$
\begin{array}{lll}
\text { Seppelt-1 } & { }^{206} \mathrm{~Pb} /{ }^{238} \mathrm{U} & 839 \pm 9 \mathrm{Ma} \\
\text { \& Seppelt-2 } & { }^{207} \mathrm{~Pb} /{ }^{235} \mathrm{U} & 839 \pm 21 \mathrm{Ma}
\end{array}
$$

Ashmore Only Proterozoic basement ages of 1841, 1873 and 2107 Ma were obtained

KGB2

$$
\begin{array}{ll}
{ }^{206} \mathrm{~Pb} /{ }^{238} \mathrm{U} & 236 \pm 3 \mathrm{M} \\
{ }^{207} \mathrm{~Pb} /{ }^{235} \mathrm{U} & 231 \pm 9 \mathrm{Ma}
\end{array}
$$

(Fig. 3)

Of considerable interest is the precise Permian age obtained for rutile from the KGB2 kimberlite dyke which has not been previously dated. No younger kimberlites have previously been recognized from the province.

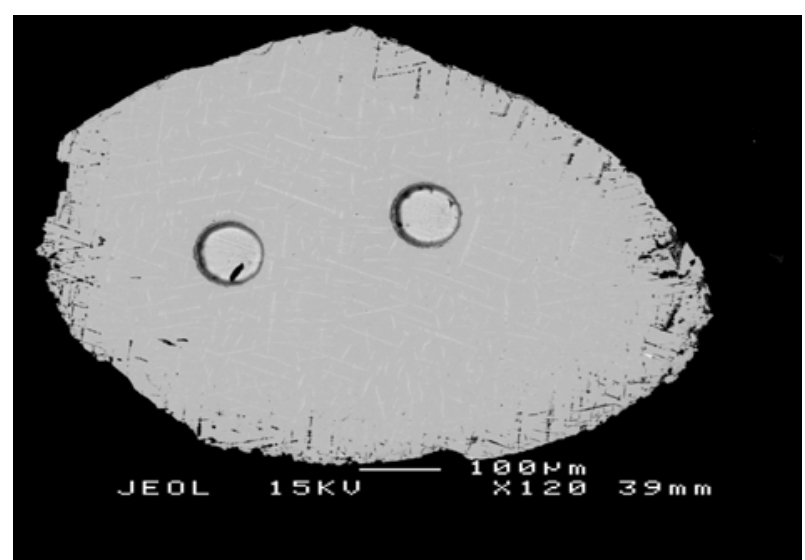

Fig. 3 Laser ablation pits in kimberlitic Nb-Cr-rutile from the KGB2 kimberlite dyke (North Kimberley Province, northwest Australia) showing Cr-spinel exsolution lamellae.

Application of rutile dating to the provenance of heavy minerals in drainage systems of the Georgina Basin, Northern Territory, Australia

Detrital rutile has been dated from mineral concentrates obtained from a present-day enclosed stream catchment within the Cambro-Ordovician Georgina Basin of the Northern Territory. Within the catchment country rocks are all older than $420 \mathrm{Ma}$. Unexpectedly the mineral concentrate contains an abundance of younger $\sim 310$ to 380 Ma rutiles (Fig. 4). This indicates that some heavy mineral have been derived from an external source outside the present-day catchment. Presumably there have been relatively recent changes to the drainage catchment involving uplift in the headwaters of the catchment and its isolation from major rivers draining younger rock units to the far southwest. Any diamond indicator minerals located within this catchment may also have an external source, considerably down grading the chances of locating a local kimberlite source by following up drainage indicator anomalies.

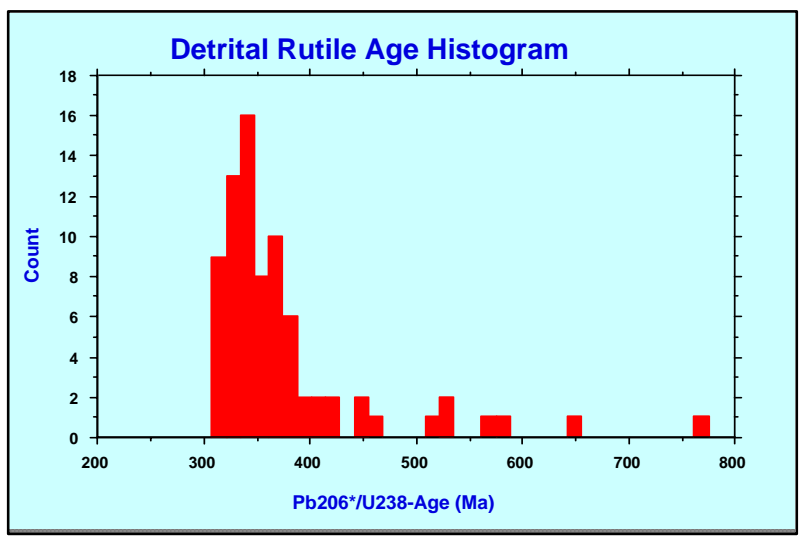

Fig. 4 Histogram of U-Pb rutile ages from a mineral concentrate obtained from samples within a presentday enclosed catchment of the Cambro-Ordovician Georgina Basin, NT, Australia.

Detrital Rutile dating is a useful tool in testing possible sedimentary rock infill in kimberlite pipes

The example shown below is a positive test of the hypothesis that a $200 \mathrm{~m}$ diameter circular feature filled with sandstone and shedding indicator chromite minerals is potential kimberlite pipe with an upper level sedimentary infill. The next stage is to drill-test the body.

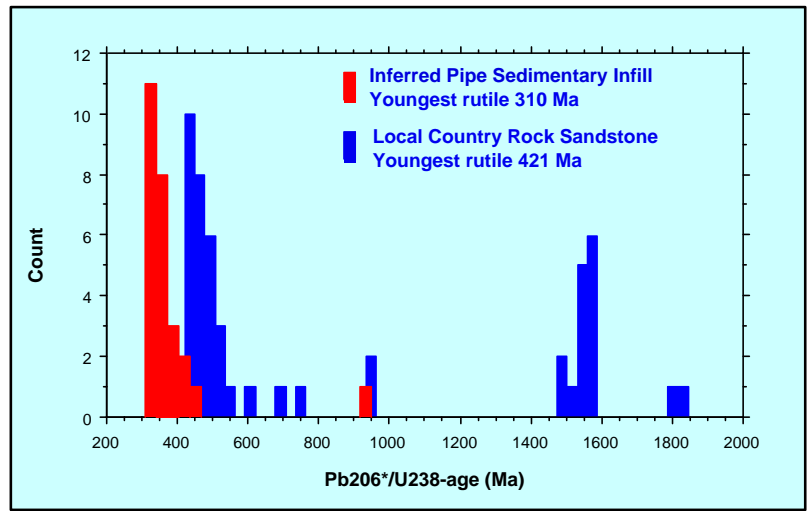

Fig. 5 Histogram of $\mathrm{U}-\mathrm{Pb}$ rutile ages from a mineral concentrate obtained from samples of an inferred sedimentary infill of a kimberlite pipe and the local country rock sandstone.

In conclusion, several novel examples of the application of rutile dating to diamond exploration have been discussed. The rapid and cost effective nature of the analyses means that results can be obtained in timely fashion before the need to employ expensive follow-up methods in the field. 